\title{
RESENHA: MENDY, PETER KARIBE. AMILCAR CABRAL: A NATIONALIST AND PAN-AFRICANIST REVOLUTIONARY. ATHENS: OHIO UNIVERSITY PRESS, 2019.
}

Camille Johann Scholl ${ }^{1}$

O livro Amílcar Cabral: a Nationalist and Pan-Africanist Revolutionary faz parte da coleção “Ohio Short Stories of Africa” e apresenta uma visão ampla da biografia de Amílcar Cabral, um “icônico líder político do século XX” que foi “um nacionalista consumado e um revolucionário panafricanista” determinado a acabar com o colonialismo português na Guiné Portuguesa - atual Guiné-Bissau - e nas Ilhas de Cabo Verde.

O autor da obra, Peter Karibe Mendy, é um guineense professor na área de história africana do Rhode Island College, em Providence (EUA). Ele possui ampla obra publicada a respeito da tradição de resistência ao colonialismo português na Guiné Portuguesa assim como sobre processos históricos que tangem a construção nacional da Guiné Bissau. De forma que, a suscinta obra sobre Amílcar Cabral abarca um esforço de síntese de um pesquisador especialista no assunto e traz referências essenciais e atuais a respeito das interpretações históricas e da produção historiográfica sobre a Guiné-Bissau.

O livro apresenta uma organização cronológica da vida e trajetória de Amílcar Cabral e é dividido em dez capítulos que tratam de um recorte temporal entre 1924 a 1973, analisando desde seu nascimento e infância, a sua formação familiar e trânsitos entre Guiné e Cabo Verde, até a implementação da luta revolucionária e seu assassinato em Conacry.

Esta obra é interessante pois apresenta de forma sintética uma apreciação dos diversos contextos dos quais Amílcar Cabral vivenciou, exibindo uma análise histórica que abarca bibliografia relevante a respeito da Guiné e do Cabo Verde em contexto colonial, entrecortando o exame da conjuntura histórica com a trajetória de vida de Amílcar Cabral. No que tange a infância e adolescência, o autor faz uma importante análise da formação social e histórica tanto da Guiné quanto de Cabo Verde, mostrando a formação e o papel das elites, assim como da construção das diferenças (e futuras rivalidades) que demarcarão o embate político entre a união da Guiné e Cabo Verde.

Na sequência, o autor trata da experiência de estudos de Cabral em Portugal, na Casa dos Estudantes do Império, capítulos aos quais vai fazer uma análise histórica interessante da

1 Doutoranda pelo Programa de Pós-Graduação em História da PUC-RS. Atualmente desenvolve sua tese de doutorado a respeito de Léopold Sédar Senghor e sua interface com a lusofonia. Mestre pela PUC-RS, desenvolveu pesquisas a respeito do discurso antropológico dentro do escopo do colonialismo português na Guiné. Licenciada e Bacharel em História pela Universidade Federal do Rio Grande do Sul. 
construção do pensamento anticolonial das figuras que se tornarão os principais "Freedom Fighters" e organizarão os movimentos contra o colonialismo português, na Guiné, Angola e Moçambique. O autor considera na análise a relação entre o acirramento do racismo sofrido quando Cabral estava em território metropolitano, em tensão com os estudos autônomos realizados pelos estudantes provindos de África sobre a cultura e história africana - sob influência do movimento da Negritude que emergiu na França na década de 30 - o que formou o Centro de Estudos Africanos, dentro da Casa dos Estudantes do Império, em Lisboa.

Neste enlevo, o autor vai tratar do retorno de Cabral para a "terra natal", significando assim, um regresso tanto geográfico - Cabral retorna para Guiné em 1952 para trabalhar como agrônomo a serviço da administração colonial - quanto um regresso cultural - no que tange um (re)conhecimento de todo o território da Guiné, ao qual percorreu por conta do censo agrícola que foi responsável, experiência que transformou seu pensamento e foi constituinte do impulso para construção do movimento anticolonial.

Assim, o autor demonstra como o movimento anticolonial se constitui, dando sentido a um binacionalismo - entre Guiné e Cabo Verde - ideia que foi motivo de desacordos quando da constituição do Partido da Independência da Guiné e Cabo Verde. Neste escopo, o autor consegue deixar bem claro como as relações políticas entre os países são constituídas naquela região, o que tange Amílcar Cabral e o PAIGC (Partido Africano para Independência da Guiné e Cabo Verde) frente à Guiné Conacry, de Sékou Touré, assim como o Senegal, liderado por Léopold Senghor.

Junto a isto, mostra a constituição do grupo que organizou o movimento anticolonial a partir da Guiné - como Aristides Pereira e Abilio Duarte, entre outros - assim como exibe, no plano geopolítico africano, a importância das conferências pan-africanas - como a Segunda Conferência de Todos os Povos Africanos, em Janeiro de 1960, a qual foi o marco do seu engajamento total na luta anticolonial a partir da Guiné.

O autor demonstra como a luta anticolonial foi construída internacionalmente, ou seja, entre diálogos dos Freedom Fighters entre Guiné, Angola e Moçambique - os quais conformam a Frente Revolucionária para Independência Nacional das Colônias Portuguesas (FRAIN) - junto a demonstração das imensas capacidades diplomáticas de Amilcar Cabral, que capitalizou auxílios econômicos, militares e políticos em diversos países (Suíça, Inglaterra, Cuba, entre outros).

De forma que o autor consegue fazer um proveitoso entrelaçamento, em um texto de fácil leitura, entre o pensamento de Amílcar Cabral e a sua trajetória dentro da luta anticolonial com o contexto do continente africano, a partir da Guiné e Cabo Verde, demonstrando que tais conjunturas 
históricas não podem ser pensadas de forma somente regionalizada, ou isolada, mas como processos mormente internacionais e extremamente intricados.

O autor consegue articular leituras de processos históricos complexos dentro desta obra que visa ser um livro de fácil acesso e de divulgação geral a respeito de contextos africanos e suas lideranças, sem perder de vista a especificidade e originalidade do pensamento deste intelectual, Amílcar Cabral, tornando este livro uma obra importante no que tange aspectos gerais das descolonizações africanas.

O epílogo do livro tange o debate a respeito do assassinato de Amílcar Cabral e as polêmicas entre a culpabilização do exército português, a relação de Cabral com Spínola, assim como a hipótese da conspiração a partir da Guiné Conacry, na figura de Sékou Touré e até as dissidências do PAIGC - que tinham pesadas discordâncias com a questão da construção do estado binacional.

Por fim, o autor realiza uma análise a respeito do que seria o legado de Amílcar Cabral, considerando a construção de uma reflexão, dentro do escopo marxista, a respeito do imperialismo, da descolonização, do necessário “suicídio de classe” e da construção das nações africanas, procurando arguir e demonstrar que, apesar da violência colonial ser combativa pela opção da guerrilha, em luta por uma independência "total e imediata” das colônias portuguesas, Cabral era um humanista, defensor “de todas as causas justas”, com foco na total libertação da África - no escopo pan-africanista - em busca do progresso social, econômico e cultural para construção da Unidade Africana. 